\title{
Pengaplikasian Sistem Informasi Pencatatan Keuangan pada Koperasi Serba Usaha Karya Mentulik
}

\author{
Astri Ayu Purwati*a , Febdwi Suryani b, Muhammad Luthfi Hamzahc \\ STIE Pelita Indonesia ${ }^{a}$ b \\ Universitas Islam Sultan Syarif Kasim Pekanbaruc \\ *astri.ayu@lecturer.pelitaindonesia.ac.id
}

\begin{abstract}
Abstrak
Kelompok tani merupakan satu wadah bagi para anggotanya untuk melakukan gerakan bersama dalam usaha pertanian. Dalam pengelolaannya, KSU-KM sebagai wadah yang menaungi kelompok petani di Desa Mentulik, Kab. Kampar, Riau memerlukan suatu manajemen pengelolaan yang bagus demi menghasilkan suatu koperasi KSU-KM yang maju dan mampu mencapai visi dan misi bersama. Untuk itu kegiatan pengabdian kepada masyarakat ini dilakukan di KSU-KM Desa Mentulik yang melibatkan seluruh pengurus Koperasi yang berjumlah 5 orang dimana dalam kegiatan ini tim pengabdian merancangkan sistem informasi berupa sistem pencatatan akuntansi. Sistem informasi tersebut dibuat dengan tujuan agar teknologi tersebut dapat membantu pengurus dalam mengelola kegiatan koperasi. pelatihan juga diberikan kepada sleuruh pengurus KSU-KM untuk memberikan pemahaman dan pengaplikasian sistem informasi tersebut. Melalui kegiatan ini, hasil evaluasi menunjukkan bahwa pengurus telah memahami dengan sangat baik dan memperoleh manfaat dari sistem informasi tersebut yang mampu membuat pekerjaan menjadi efektif dan efisien.
\end{abstract}

Keywords: Sistem Informasi, Sistem Pencatatan Akuntansi, SMS Gateway Website, Koperasi

\section{Pendahuluan}

Desa Mentulik merupakan merupakan sebuah desa yang terdapat di kecamatan Kampar Kiri Hilir, Kabupaten Kampar, provinsi Riau, Indonesia. Desa mentulik berada di sepanjang aliran sungai Kampar kiri dimana hal ini menyebabkan kondisi tanah yang rawa sangat membantu masyarakat untuk dapat mengembangkan usaha sektor pertanian, perkebunan dan perikanan. Keberadaan sungai Kampar Kiri ini juga membantu masyarakat sekitar dalam memanfaatkan kekayaan laut untuk memenuhi kebutuhan dan sebagai mata pencaharian. Salah satu jenis pertanian yang berkembang pesat di desa mentulik ini adalah jenis pertanian kelapa sawit.

Dengan dituntutnya suatu pengelolaan koperasi kelompok tani yang berkualitas dan professional tentulah diperlukan pula pengelola yang baik. Namun, berbagai keterbatasan yang ada di KSU Karya mentulik menyebabkan terjadinya beberapa kendala dan permasalahan dalam proses pengelolaan KSU Karya Mentulik. Adapun beberapa masalah tersebut di antaranya : Pertama, Kesalahan pencatatan dalam administrasi keuangan koperasi. Sistem pembukuan yang dilakukan oleh Pengurus KSU Karya Mentulik masih bersifat manual dan masih banyak kesalahan-kesalahan yang dilakukan saat pencatatan. Selain itu, kurangnya kemampuan dan kompetensi pengurus KSU Karya Mentulik dalam melakukan pembukuan seperti pencatatan laporan kas masuk dan kas keluar, laporan laba/keuntungan, laporan neraca dan pembuatan laporan pertanggungjawaban. Sesuai dengan prinsip koperasi yang pendiriannya dilakukan demi tujuan bersama, maka dari itu pengelolaan koperasi yang baik haruslah transparan, agar anggota 
percaya dengan keberadaan koperasi, termasuk dalam program-program kerjanya harus transparan agar anggota bisa mengetahuinya, bahkan yang paling penting adalah laporan keuangan koperasi haruslah benar dan transparan (Skyrius et al., 2013). Untuk itu, jika kesalahan-kesalahan seperti ini dibiarkan maka akan mengganggu pembukuan keuangan koperasi dan menyebabkan kurangnya kepercayaan dari para anggota KSU Karya Mentulik.



\section{Metode}

Adapun metode pelaksanaan kegiatan ini terdiri tahapan perancangan, pelatihan dan bimbingan, implementasi dan evaluasi:

Tahapan perancangan, adapun tahapan ini terdiri dari Perancangan Sistem Pencatatan Akuntansi yaitu Sistem aplikasi keuangan ini dibuat untuk mengoptimalkan pekerjaan dari pengurus KSU Karya Mentulik dalam pelaporan keuangan yang sebelumnya manual menjadi terkomputerisasi.

Tahapan pelatihan dan bimbingan, Pelatihan dan Sosialisasi Penggunaan Sistem Informasi Koperasi dilakukan kepada seluruh pengurus KSU Karya mentulik pada hari sabtu tanggal 20 Juli 2019 di Kantor KSU-KM desa Mentulik, Kab. Kampar, Riau. Adapun pelatihan ini dihadiri oleh sebanyak 5 orang pengurus KSU-KM.

Tahapan implementasi, Tahapan ini terdiri dari : Pengimplementasian penggunaan Sistem Administrasi Keuangan yang sudah di rancang oleh Tim Pengusul untuk digunakan dalam pembukuan koperasi.

Tahapan Evaluasi, Dalam tahapan ini proses pengukuran terhadap Efektivitas dan Efisiensi penggunaan sistem administrasi keuangan.

\section{Hasil dan Pembahasan}

\section{Perancangan Kebutuhan Sistem Informasi}

Sistem Informasi Keuangan adalah sistem informasi yang memberikan informasi kepada orang atau kelompok baik di dalam perusahaan maupun di luar perusahaan mengenai masalah keuanganan \& menyediakan informasi mengenai arus uang bagi para pemakai diseluruh perusahaan (Esmeray 2016). Sistem 
informasi keuangan pada KSU Karya mentulik dibuat melalui perancangan aplikasi pelaporan keuangan berbasis desktop yang bertujuan agar pekerjaan dapat lebih aman, akurat dan efisien. Sistem aplikasi keuangan ini dibuat untuk mengoptimalkan pekerjaan dari pengurus KSU Karya Mentulik dalam pelaporan keuangan yang sebelumnya manual menjadi terkomputerisasi.

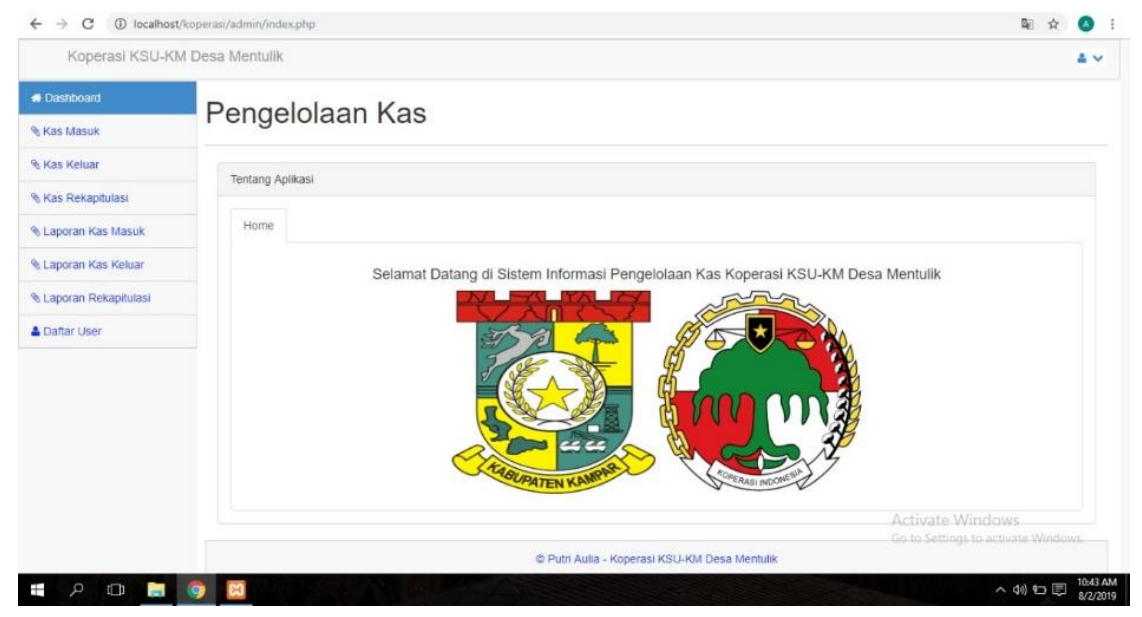

Sumber : Data diolah (2019)

Gambar 2. Sistem informasi akuntansi KSU-KM

\section{Pelaksanaan Pelatihan Program Sistem Informasi}

Pelatihan Program Sistem Informasi dilakukan di Koperasi Serba Usaha (KSU) Karya Mentulik pada hari Sabtu tanggal 20 Juli 2019. Pelatihan ini melibatkan beberapa orang pengurus KSU-KM sebagai berikut :
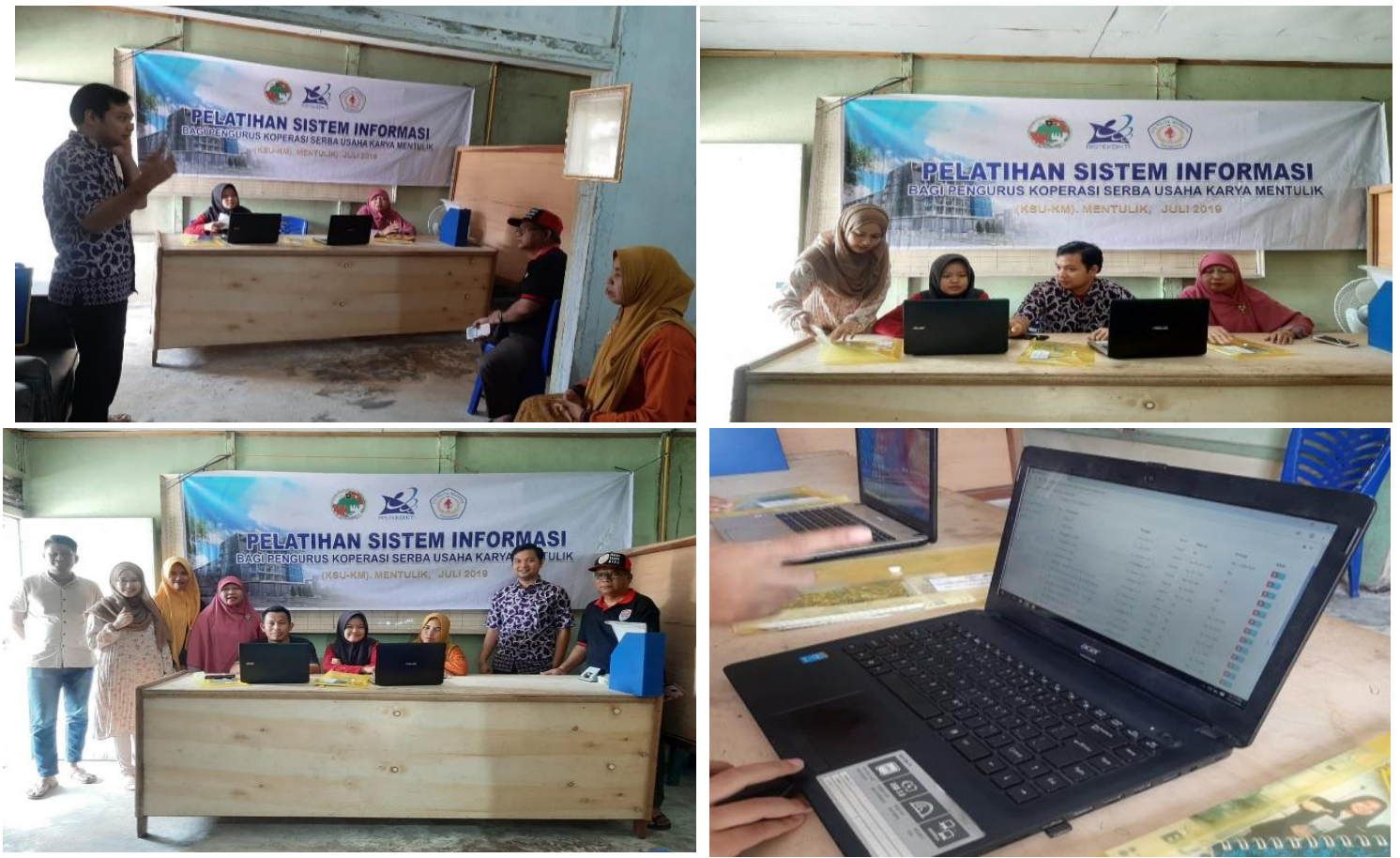

Sumber : Dokumentasi Tim (2019)

Gambar 3. Kegiatan Pelatihan Sistem Informasi KSU-KM 


\section{Implementasi dan Evaluasi Sistem Informasi Koperasi}

Setelah melakukan perancangan sistem informasi koperasi dan memberikan pelatihan kepada pengurus koperasi dalam menggunakan sistem, selanjutnya untuk mengevaluasi keberhasilan sistem tersebut maka dilakukan penyebaran kuesioner kepada pengurus yang terlibat dalam pengelolaan sistem dimana hasil yang diperoleh adalah sebagai berikut :

Tabel 1. Hasil Penyebaran Kuesioner Evaluasi Keberhasilan Sistem

\begin{tabular}{clccc}
\hline No & \multicolumn{1}{c}{ Pertanyaan } & Rata-Rata & Keterangan \\
\hline \multicolumn{1}{c}{$\begin{array}{l}\text { Kemudahan menggunakan Sistem Pencatatan } \\
\text { Akuntansi KSU-KM }\end{array}$} & 4.4 & Sangat Baik \\
$\begin{array}{l}\text { Pemahaman menggunakan Sistem Pencatatan } \\
2\end{array}$ & $\begin{array}{l}\text { Akuntansi KSU-KM } \\
\text { Sistem Pencatatan Akuntansi } \\
\text { membantu pekerjaan administrasi } \\
\text { koperasi tertata dengan baik }\end{array}$ & keuangan & 4.6 & Sangat Baik \\
\hline Rata-Rata & $\mathbf{4 . 4}$ & Sangat Baik \\
\hline
\end{tabular}

Dari data kuesioner hasil evaluasi di atas dapat dilihat bahwa rata-rata respon pengurus koperasi dalam pemahamannya serta manfaat dari sistem informasi koperasi ini adalah sangat baik yang artinya sistem informasi koperasi ini dapat di implementasikan dengan baik bagi membantu memudahkan pekerjaan dan pengelolaan koperasi sehari-harinya. Selain itu, dalam kegiatan ini tim pengabdian juga memberikan bantuan kepada koperasi KSU-KM berupa 1 unit laptop dan model serta papan nama koperasi yang baru disebabkan oleh papan nama koperasi yang lama sudah rusak.

\section{Simpulan}

Melalui kegiatan pengabdian kepada masyarakat ini diharapkan dapat memberikan manfaat demi terciptanya pengelolaan koperasi berbasis teknologi yang mampu memudahkan seluruh pengurus dan anggota koperasi dalam hal perbaikan pembukuan serta berbagi informasi. Ke depannya di harapkan kegiatan pengabdian ini dapat terus terlaksana bagi memajukan koperasi KSU-KM bukan hanya dari segi pengelolaan namun juga dari segi pemasaran agar mampu meningkatkan daya saing koperasi dalam menghasilkan produk tandan sawit berkualitas.

\section{Ucapan Terima Kasih}

Ucapan terima kasih di ucapkan kepada Direktorat Riset dan Pengembangan Kementrian Riset, Teknologi dan Pendidikan Tinggi yang telah memberikan pendanaan Hibah Program Kemitraan Masyarakat (PKM) tahun 2019 untuk menjalankan kegiatan ini.

\section{Daftar Pustaka}

Esmeray, A. (2016). The Impact of Accounting Informations Systems on Firm Performance : Empirical Evidence in Turkish Small and Medium Sized Enterprises. International Review of Management and Marketing, 6(2), 233-236. 
Jimoh, R. G., Coco, K. B., \& Oluobo, Abdel, M. F. O. (2013). Design Of Mobile Short Message Service (SMS) Across A Computer Network For Organisational Communication. International Journal of Computer Applications Technology and Research, 2(4), 409 - 414

Partomo, T.S., \& Soejoedono, A.R. (2004). Ekonomi Skala Kecil / Menengah dan Koperasi. Ghalia Indonesia. Jakarta.

Purwati, A.A., \& Handani, C.S. (2017). Perancangan Akuntansi pada Toko Kita. Bilancia: Jurnal Ilmiah Akuntansi, 4(1), 440-457.

Skyrius, Rimvydas., Kazakevičienè, Gèlytè., \& Vytautas, Bujauskas. (2013). From Management Information Systems to Business Intelligence: The Development of Management Information Needs. International Journal of Artificial Intelligence and Interactive Multimedia, 2(3), 31-37.

Yuwono, Triwibowo. (2011). Pembangunan Pertanian: Membangun Kedaulatan Pangan. Gajah Mada University Press. Yogyakarta 